\title{
Ovarian characteristics and reproductive performance of reindeer, Rangifer tarandus
}

\author{
N. Leader-Williams* and Alison M. Rosser* \\ British Antarctic Survey, Natural Environment Research Council, Madingley Road, \\ Cambridge, CB3 OET, U.K.†
}

\begin{abstract}
Summary. A total of 301 female reindeer of various ages was shot on South Georgia in all months of the year to study seasonal and age-related changes in ovarian structures, and to undertake an intraspecific comparison with North American caribou. Ovarian weights and follicle numbers did not change in reindeer calves, and it is concluded that the South Georgia population do not attain physiological puberty in their first year. Compared with caribou, reindeer showed an earlier onset of ovarian activity, and had twice as many follicles $>2 \mathrm{~mm}$ diameter and secondary corpora lutea. The relationship between luteal scars and age was significant $(P<0 \cdot 001)$, despite an overcount of scars relative to age in some individuals, and indicated a fecundity rate of 0.93 . The left and right ovaries of reindeer were equally productive. It remains unclear whether the differences in reproductive performance between reindeer and caribou are of genetic origin.
\end{abstract}

\section{Introduction}

Eurasian reindeer and North American caribou (Rangifer tarandus) are found at the highest latitudes of any deer species. Females ovulate spontaneously and mate during September and October; implantation is not delayed and estimates of the gestation period vary between 209 and 240 days (Preobrazhenskii, 1961; Dott \& Utsi, 1973; Bergerud, 1975). A single calf is born during a highly restricted calving season with a peak of some 2 weeks, the timing of which varies between reindeer and caribou populations, and occurs during May and June (Dauphiné \& McClure, 1974; Holthe, 1975; Bergerud, 1975).

A major difference between reindeer and caribou lies in their reproductive performances. Reindeer in their natural habitats generally first conceive in their 2 nd year of life, and at this age and onwards have pregnancy rates approaching 90\% (Preobrazhenskii, 1961; Skuncke, 1969). In contrast, caribou first conceive usually at an older age and only gradually increase their pregnancy rates to $90 \%$ in their 4 th or 5 th year of life (Dauphiné, 1976). For reindeer only a small series of ovarian weights (Roine, 1970) and a description of ovarian histology (Borozdin, 1969) are available and there are no data on ovarian characteristics in relation to reproductive performance. This paper describes seasonal changes in structures present in ovaries of reindeer introduced to the subantarctic island of South Georgia. These data are used for an intraspecific comparison between reindeer and Canadian barren-ground caribou (Dauphiné, 1978).

* Present address: Large Animal Research Group, Department of Zoology, 34A Storey's Way, Cambridge CB3 0DT, U.K.

† Address for reprints. 


\section{Materials and Methods}

Study area

The study was undertaken on South Georgia, a subantarctic island lying between $53^{\circ} 30^{\prime}$ and $55^{\circ} \mathrm{S}$ and $35^{\circ} 30^{\prime}$ and $38^{\circ} 30^{\prime} \mathrm{W}$. Two different genetic stocks of Norwegian reindeer were introduced onto the island in 1911 and 1925, and now form three discrete herds: (1) the Barff herd, from which an unknown number of reindeer emigrated in 1964 to form (2) the Royal Bay herd, and (3) the Busen herd (Leader-Williams, 1980). The breeding season of these reindeer was reversed 2 years after transfer across the equator, and the females now calve in November, the austral spring (Olstad, 1930). The rut occurs in the last 2 weeks of March and the first 2 weeks of April (LeaderWilliams, 1979a). The reproductive performance of females on South Georgia is similar to that in their Northern Hemisphere counterparts: conceptions first occur in yearlings of 16-17 months, and pregnancy rates reach $90 \%$ (Leader-Williams, 1980).

\section{Field studies}

Female reindeer of various ages were shot as follows: 183 from the Barff herd between May 1974 and November 1975; 58 from the Royal Bay herd between December 1973 and February 1974, and during the same months in 1975 to 1976; and 60 from the Busen herd during 6 different months between August 1974 and February 1976. During the course of a full dissection of each animal, the uterus and ovaries were removed by cutting at the cervix and at the broad and ovarian ligaments. The uterus was examined to determine pregnancy rates (Leader-Williams, 1980), and the ovaries were trimmed and fixed in $10 \%$ formal-saline.

\section{Laboratory studies}

Age determination. The ages of reindeer were determined by a combination of tooth eruption patterns and annulations in decalcified sections of incisor teeth (Leader-Williams, 1979b). The age in years was assumed to increase by 1 on 15 November (the midpoint of the month of birth) and the age in months to increase on the 15th day of each month. Data from the same months of different years of the study were combined to present the annual cycle.

Ovarian sectioning and histology. Left and right ovaries were weighed separately. Each ovary was sliced sagittally into $\sim 0.5-\mathrm{mm}$ sections joined at their hilar edges, and sections were backlighted for macroscopic identification of follicular and luteal structures, the various types of which are illustrated by Dauphiné (1978). Counts of different structures were checked independently by both authors; these were not compared with the age of the animal until agreement had been reached on the numbers of each structure present. The maximum and minimum diameters across the exposed face of each structure were measured with vernier calipers, and the two diameters were averaged. On the basis of measurements provided by Dauphine (1978) for caribou, the following were identified: follicles of $2-5,5-8$, and $\geqslant 8 \mathrm{~mm}$ throughout the annual cycle; corpora lutea (CL) of pregnancy and their accompanying secondary $C L$ if present from April to November; regressing CL from November until March; luteal scars from previous pregnancies throughout the annual cycle. The term CL of ovulation is preferred for the structure described by Dauphine (1978) as CL of oestrus, for it arises after ovulation and not during the oestrous period (Harrison, 1962). These structures were identified in non-pregnant females, but there was an insufficient sample from March and April to determine ovulation rates as done by Dauphiné (1978).

Certain ovaries from the Barff and Busen herds were sectioned serially in the routine manner for light microscopy, and examined at magnifications varying from $\times 50$ to $\times 500$, as follows: both ovaries from all calves collected between April and August, to check for the presence of luteal structures, and an initial sample of 20 ovaries from yearling and adult females to determine whether 
regressed luteal structures were from $\mathrm{CL}$ of pregnancy or secondary $\mathrm{CL}$. After examination of this initial sample, further sections were not prepared.

Statistical analysis. Results from the Barf herd are presented in detail, and compared subsequently with the smaller samples from the other two herds. Differences in the weights of ovaries were compared by Student's $t$ test and by analysis of variance. The numbers of follicles were ranked and compared by the Mann-Whitney $U$ test and by the Kruskal-Wallis one-way analysis of variance. Differences in diameters of CL of pregnancy were compared by Student's $t$ test, and those in the frequencies of occurrence of secondary $C L$ by $\chi^{2}$ test. The slope and intercepts of regression lines of luteal scars on age were compared by analysis of variance.

\section{Results}

\section{Barff herd}

Ovary weight. Ovary weights differed between left and right sides in $79 \%$ of non-pregnant, nulliparous females; the average weight of both ovaries is therefore shown in Text-fig. 1. Ovarian weights of calves $<12$ months of age did not change during the annual cycle $(F=1 \cdot 82$, d.f. $=5,42$,

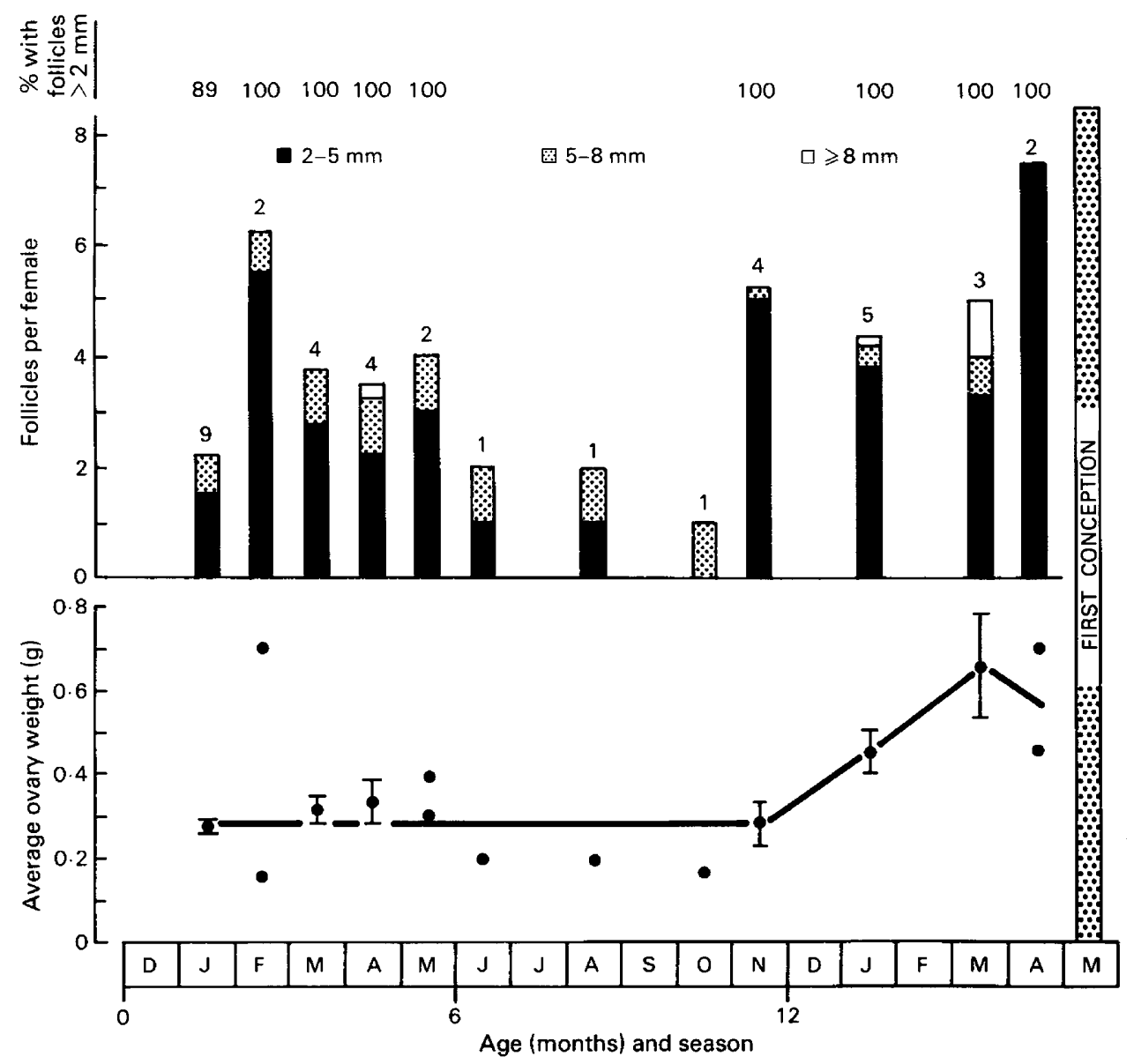

Text-fig. 1. The average ovary weights (mean \pm s.e.m. shown only for 3 or more females per month class) and follicle numbers in 28 reindeer calves and 10 non-pregnant, nulliparous yearlings. Sample sizes are shown above follicle numbers. 
$P>0 \cdot 10)$, but those of yearlings aged $12-16$ months changed significantly $(F=5 \cdot 11$, d.f. $=3,24$, $P<0.01$ ).

Ovary weights of breeding reindeer (females that were pregnant or had conceived during the annual cycle of their collection) are shown by month in Text-fig. 2. Both ovaries decreased in weight after early pregnancy, and then increased and declined before parturition. The ovary with the $C L$ of pregnancy continued its post-partum decrease in weight, and the weights of both ovaries increased during pro-oestrus. Ovary weights of pregnant reindeer are also shown by age class in Text-fig. 3. The ovaries bearing the $\mathrm{CL}$ of pregnancy and the contralateral ovaries showed significant (both $P<0.001$ ) and parallel increases in weight with age.

Changes in follicle numbers and size with age and season. As shown in Text-fig. 1, follicles $>2 \mathrm{~mm}$ in diameter were found in all calves except one, and there was no significant change in the total number of follicles during the first annual cycle $(H=10.36$, d.f. $=5, P>0.05)$. All follicles $>5$

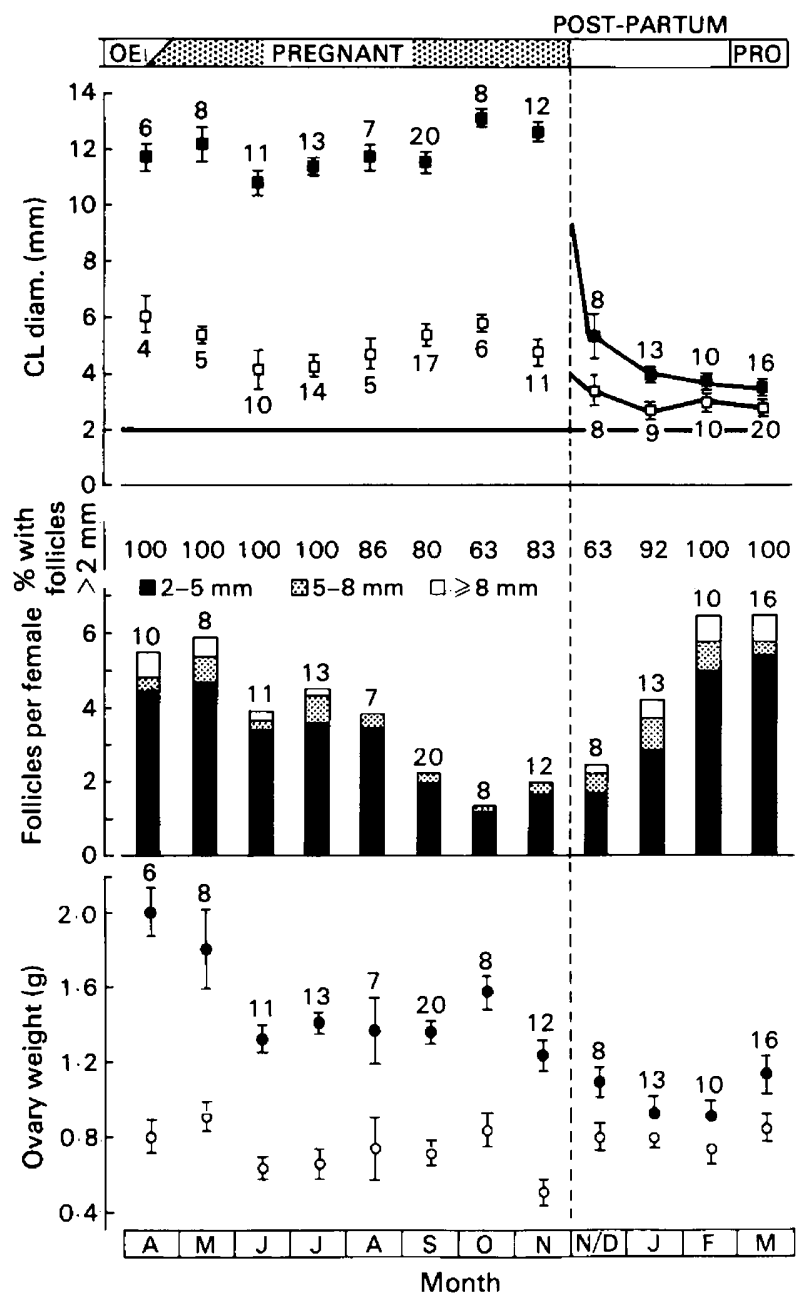

Text-fig. 2. The mean \pm s.e.m. weights of ovaries bearing the CL of pregnancy and contralateral ovaries; follicle numbers; and mean \pm s.e.m. diameter of $C L$ of pregnancy and secondary $C L$ in 136 breeding reindeer. Sample sizes are shown as appropriate. Oe = oestrus; Pro $=$ pro-oestrus. The broken vertical line represents parturition. The solid horizontal line represents the maximum diameter of luteal scars. 


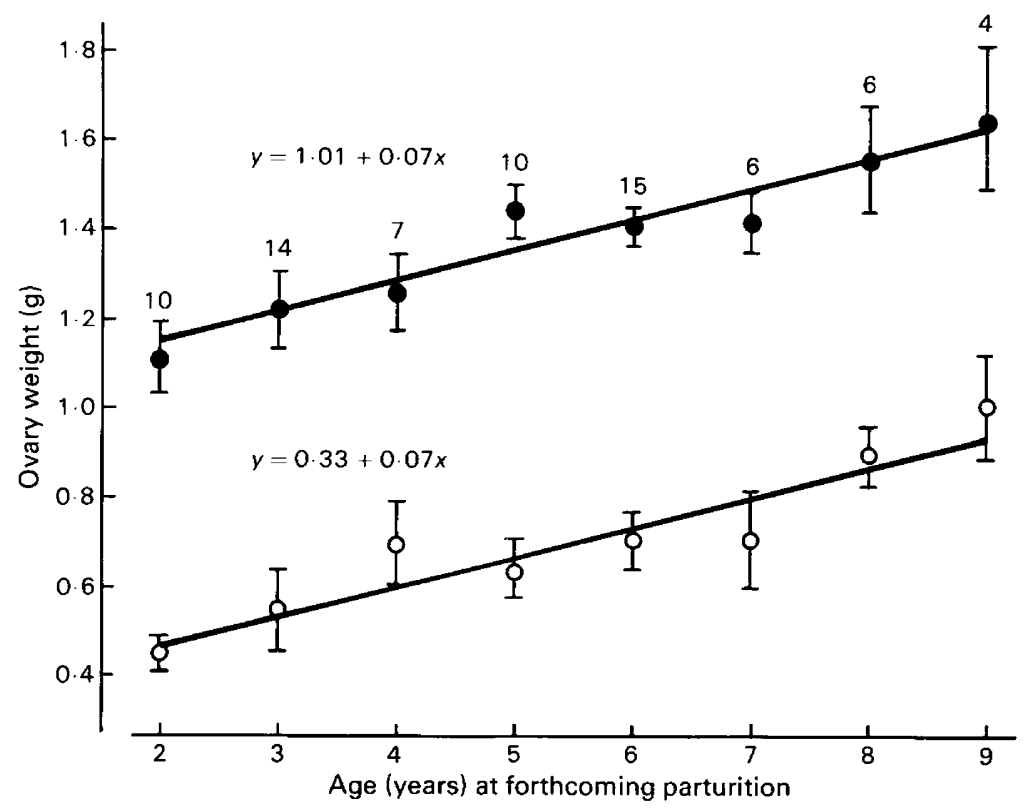

Text-fig. 3. Regression of weights of ovaries bearing the CL of pregnancy (O) and of the contralateral ovaries $(O)$ on the age of 72 pregnant reindeer. Sample sizes and the respective regression equations are shown.

$\mathrm{mm}$ in diameter in calves collected from April to August appeared to have reached maturity, but the lack of luteal tissue indicated a failure of ovulation.

Follicle numbers and size in breeding females (Text-fig. 2) increased to attain their maxima around pro-oestrus and oestrus, but a marked decline in number and size occurred only in the last half of pregnancy. At the start of this decline in August many follicles were atretic, as shown by the presence of pycnotic granulosa cells and degenerating ova.

Functional and secondary CL of pregnancy. The CL of pregnancy was always ipsilateral to the uterine horn occupied by the fetus. These CL varied in diameter (Text-fig. 2) throughout pregnancy in a pattern similar to that for. weights of the ovary bearing the CL of pregnancy.

Secondary CL were distinguished from CL of pregnancy by their smaller diameter (Text-fig. 2). Most females had a single secondary CL (Table 1), and these CL were distributed evenly between the two ovaries. The frequencies of secondary CL did not change $\left(\chi^{2}=4 \cdot 73\right.$, d.f. $\left.=7, P>0 \cdot 10\right)$ throughout the different months of pregnancy.

Regressing $C L$. The diameters of regressing CL of pregnancy declined rapidly after parturition, in contrast to those of secondary CL (Text-fig. 2). The diameters of secondary CL remained smaller than those of CL of pregnancy throughout the post-partum period (January: $t=5 \cdot 67$, d.f. $=20, P<$ 0.001 ; February: $t=2.17$, d.f. $=18, P<0.05$; March: $t=4.21$, d.f. $=34, P<0.001$ ), but the secondary CL were larger, lighter in colour and less distorted than luteal scars, which were invariably $<2 \mathrm{~mm}$ in diameter. The fact that secondary CL could be identified macroscopically throughout the post-partum period was supported further by numerical data (Table 1); the frequencies of occurrence in pregnant and post-partum females were similar ( 78 and $79 \%$ ). In addition, the distribution of secondary CL in the 2 ovaries and the frequency of multiple secondary CL did not differ $\left(\chi^{2}=0.79\right.$, d.f. $=1, P>0.10$ and $\chi^{2}=4.94$, d.f. $\left.=2, P>0.05\right)$ in post-partum and pregnant females.

When a new CL of pregnancy formed in April, regressing secondary CL were no longer always macroscopically distinguishable from luteal scars. In reindeer (Borozdin, 1969) and caribou 
Table 1. Numbers, distribution and relative occurrence of secondary CL in ovaries of breeding reindeer

\begin{tabular}{|c|c|c|c|c|c|c|c|c|}
\hline \multirow[b]{3}{*}{ Herd } & \multirow{3}{*}{$\begin{array}{l}\text { Reproductive } \\
\text { state }\end{array}$} & \multirow{3}{*}{$\begin{array}{l}\text { Month or } \\
\text { total }\end{array}$} & \multirow{3}{*}{$\begin{array}{c}\text { No. of } \\
\text { females } \\
\text { with CL of } \\
\text { pregnancy }\end{array}$} & \multicolumn{3}{|c|}{ No. of secondary $\mathrm{CL}$} & \multirow{2}{*}{\multicolumn{2}{|c|}{$\begin{array}{l}\text { Females with } \\
\text { secondary } C L\end{array}$}} \\
\hline & & & & \multirow{2}{*}{$\begin{array}{l}\text { In ovary } \\
\text { with CL of } \\
\text { pregnancy }\end{array}$} & \multirow{2}{*}{$\begin{array}{l}\text { In opposite } \\
\text { ovary }\end{array}$} & \multirow[b]{2}{*}{ Total* } & & \\
\hline & & & & & & & No.* & $\%$ \\
\hline \multirow[t]{9}{*}{ Barff } & Pregnancy & April & 6 & 3 & 1 & 4 & 4 & 67 \\
\hline & & May & 8 & 3 & 2 & 5 & 5 & 63 \\
\hline & & June & 11 & 4 & 6 & $10 \dagger$ & 8 & 73 \\
\hline & & July & 13 & 11 & 3 & $14 \dagger$ & 12 & 92 \\
\hline & & August & 7 & 1 & 4 & 5 & 5 & 71 \\
\hline & & September & 20 & 6 & 11 & $17 \dagger$ & 15 & 75 \\
\hline & & October & 8 & 3 & 3 & 6 & 6 & 75 \\
\hline & & November & 12 & 4 & 7 & 11 & 11 & 92 \\
\hline & & Total & 85 & 35 & 37 & 72 & 66 & 78 \\
\hline Barff & Post partum & Total & 47 & 19 & 28 & $47 \ddagger$ & 37 & 79 \\
\hline $\begin{array}{r}\text { Royal } \\
\text { Bay }\end{array}$ & Post partum & Total & 26 & 14 & 12 & $26 \S$ & 18 & 69 \\
\hline Busen & $\begin{array}{l}\text { Pregnancy } \\
\text { and } \\
\text { post partum }\end{array}$ & Total & 46 & 21 & 35 & $56 \pi$ & 43 & 93 \\
\hline
\end{tabular}

* Discrepancies between columns occur when 1 reindeer had 2 or 3 secondary $C L$, as follows:

$\dagger 2$ females with 2 secondary $\mathrm{CL}$;

$\ddagger 8$ females with 2 and 1 with 3 secondary $C L$;

$\$ 8$ females with 2 secondary $\mathrm{CL}$;

T 11 females with 2 and 1 with 3 secondary CL.

(Dauphiné, 1978), the main differences between functional CL of pregnancy and secondary CL lies in their degree of vascularity, and in this study we found that as capillaries became compressed and connective tissue invaded the regressed structures, differentiation between the two types of structures, now of similar diameters, became unrealistic. After the initial sample, therefore, routine histology was not undertaken and all regressed luteal structures were classified macroscopically as luteal scars in samples collected from April until parturition.

Counts of luteal scars. No luteal scars or regressing CL of pregnancy were found in females in the 1 -year-old age class at the previous calving season, and this accorded with the lack of pregnancies or ovulations in calves. Counts of luteal scars were made in both ovaries of reindeer $>1$ year of age; in those collected during the post-partum period, the count was increased by 1 when a regressing $\mathrm{CL}$ of pregnancy was present, to include the recent pregnancy. A proportion $(38 \%)$ of females $>2$ years of age had lower counts than the maximum number expected for their age classes. However, and in contrast to caribou (Dauphiné, 1978), a proportion (29\%) had a scar count which exceeded that expected. This indicated that regressed secondary CL persisted in reindeer for longer than the post-partum period, and that some were counted as luteal scars; however, no attempt was made to determine whether scars originated from $\mathrm{CL}$ of pregnancy or secondary CL. Even so, the regression of luteal scars $(y)$ on age $(x)$ for 155 reindeer $>1$ year of age was significant $(r=0.87, P<0.001)$ and of the form $y=-0.81+0.93 x$. Furthermore, the slope (= fecundity rate) of 0.93 was in close agreement with the value of 0.90 derived from examination of uteri (Leader-Williams, 1980).

Left versus right ovulation. In pregnant reindeer, CL of pregnancy occurred 43 times on the left, and 42 times on the right side; the respective figures for regressing CL of pregnancy were 33 and 24. The ratio for all $\mathrm{CL}$ of pregnancy did not differ from unity $\left(\chi^{2}=0 \cdot 38, P>0 \cdot 10\right)$ between left and right sides.

In 87 pregnant and post-partum reindeer $>3$ years of age at their last parturition, the functional or regressing CL of pregnancy occurred in 36 ovaries with fewer scars than the contralateral ovary 
and in 37 ovaries with more scars. Furthermore, luteal scars occurred in equal numbers in the remaining 14 pairs of ovaries. Therefore, the CL of pregnancy did not occur more frequently $\left(\chi^{2}=\right.$ $0.98, P>0 \cdot 10$ ) in the ovary of the pair with most scars. These data are supported by the parallel increases in weight of left and right ovaries with age (Text-fig. 3), due to the even accumulation of luteal scar tissue.

Non-breeding females. Of the females $>1 \frac{1}{2}$ years of age, 8 collected from April to November were not pregnant, and 1 female lacked a regressing $C L$ of pregnancy during the post-partum period (Table 2). Of these reindeer, 3 young ( $\leqslant 3$ years) females had not bred, and 3 others had single luteal scars, suggestive of a previous or failed pregnancy. The older ( $\geqslant 6$ years) females each had several luteal scars and were not considered to have been infertile in previous seasons.

\section{Herd differences}

Royal Bay herd. The average ovary weight of yearlings collected in January at 13-14 months of age $(t=0.89$, d.f. $=30, P>0 \cdot 10)$, and the weights of ovaries containing regressing CL of pregnancy or no CL of pregnancy of post-partum reindeer $(t=0.33$ and $0 \cdot 28$, d.f. $=32, P>0 \cdot 10)$ did not differ between the Royal Bay and Barff herds. There was also no difference in the number of follicles $>2 \mathrm{~mm}$ in diameter in yearlings $\left(U=12 \cdot 5, n_{1}=9, n_{2}=5, P>0.05\right)$, but more follicles $(z$ $=2.67, P<0.005)$ were found in adult females in the Royal Bay herd.

The numbers of regressing secondary $C L$ in post-partum reindeer from the Royal Bay herd are shown in Table 1, and their frequency did not differ $\left(\chi^{2}=0.82\right.$, d.f. $\left.=1, P>0.10\right)$ from that in the Barff herd. No luteal structures were found in the ovaries of yearling reindeer $(N=11)$ in the Royal Bay herd. The regression of luteal scars $(y)$ on age $(x)$ was significant $(r=0.88, P<0.001)$ and of the form $y=-0 \cdot 72+1 \cdot 01 x$; neither the slope $(F=1.49$, d.f. $=1,192, P>0 \cdot 10)$ nor intercept $(F$

Table 2. Ovarian data for non-breeding reindeer during the breeding season and post-partum period

\begin{tabular}{|c|c|c|c|c|c|c|c|c|c|c|}
\hline \multirow{2}{*}{$\begin{array}{l}\text { Herd and } \\
\text { period of } \\
\text { occurrence }\end{array}$} & \multirow{2}{*}{$\begin{array}{l}\text { Age at } \\
\text { calving } \\
\text { season* } \\
\text { (years) }\end{array}$} & \multirow[b]{2}{*}{ Month } & \multicolumn{2}{|c|}{$\begin{array}{l}\text { Ovary weight } \\
\text { (g) }\end{array}$} & \multicolumn{3}{|c|}{$\begin{array}{l}\text { No. of follicles } \\
\text { (mm diam.) }\end{array}$} & \multirow{2}{*}{$\begin{array}{l}\text { No. of CL } \\
\text { (type } \dagger \text {, diam. } \\
\text { in } \mathrm{mm} \text { ) }\end{array}$} & \multirow{2}{*}{$\begin{array}{l}\text { No. of } \\
\text { luteal } \\
\text { scars }\end{array}$} & \multirow[b]{2}{*}{ Remarks } \\
\hline & & & L & $\mathbf{R}$ & $2-5$ & $5-8$ & $>8$ & & & \\
\hline \multirow{9}{*}{$\begin{array}{l}\text { Non-pregnant } \\
\text { Barff }\end{array}$} & $\cdot$ & & & & & & & & & \\
\hline & 2 & June & $0 \cdot 2$ & $0-2$ & 11 & - & - & 1 (ov.) & - & \\
\hline & 2 & Oct. & 0.5 & 0.4 & 2 & - & - & - & - & \\
\hline & 3 & June & $0 \cdot 1$ & $0 \cdot 3$ & 5 & - & - & 1 (ov.) & - & Nulliparous \\
\hline & 3 & June & $0 \cdot 5$ & 0.3 & - & - & - & 2 (ov.) & 1 & Parous \\
\hline & 3 & June & 0.4 & 0.4 & 1 & - & 一 & - & 1 & $\begin{array}{l}\text { Prolapsed uterus, } \\
\text { parous }\end{array}$ \\
\hline & 6 & July & 0.9 & $1 \cdot 0$ & 5 & 1 & - & 3 (ov.) & 4 & Parous \\
\hline & 8 & June & $1 \cdot 7$ & $0 \cdot 6$ & 4 & 1 & - & $\begin{array}{l}1 \text { (preg., 11) } \\
1 \text { (sec.) }\end{array}$ & & Parous \\
\hline & 8 & Nov. & $1 \cdot 0$ & $1 \cdot 1$ & 3 & 1 & - & 1 (preg., 3) & 7 & $\begin{array}{l}\text { Fetal loss (?), } \\
\text { parous }\end{array}$ \\
\hline Busen & 6 & Oct. & $1 \cdot 2$ & 0.6 & - & - & - & $\begin{array}{l}1 \text { (preg., 10); } \\
2 \text { (sec.) }\end{array}$ & 3 & $\begin{array}{l}\text { Fetal loss (?) } \\
\text { parous }\end{array}$ \\
\hline \multicolumn{11}{|l|}{ Post-partum } \\
\hline Barff & 3 & Jan. & 0.9 & 0.9 & 8 & - & 1 & - & 1 & Parous \\
\hline \multirow[t]{2}{*}{ Royal Bay } & 2 & Jan. & 0.8 & 0.4 & 4 & - & 1 & & - & Nulliparous \\
\hline & 2 & Jan. & 0.6 & $1 \cdot 2$ & 2 & - & - & $\begin{array}{l}1 \text { (preg., 11); } \\
2 \text { (sec.) }\end{array}$ & - & $\begin{array}{l}\text { Pyometritis and } \\
\text { persistent } \mathrm{CL}\end{array}$ \\
\hline Busen & 2 & Dec. & $0 \cdot 2$ & $0 \cdot 2$ & 3 & - & - & - & 4 & Nulliparous \\
\hline
\end{tabular}

* From April to November, age at forthcoming calving season; from December to March, age at previous calving season.

† ov. = ovulation; preg. = pregnancy; sec. = secondary. 
$=3 \cdot 81$, d.f. $=1,193, P>0 \cdot 10)$ differed from that of the Barff herd. Data from 2 non-breeding females are shown in Table 2.

Busen herd. The average ovary weights of calves $(F=2.57$, d.f. $=3,16, P>0 \cdot 10)$ and the numbers of follicles $>2 \mathrm{~mm}$ in diameter $(H=6.91$, d.f. $=3, P>0.05)$ did not change during the annual cycle. Small differences between the Busen and Barff herds in the follicle numbers of breeding females were not significant, but there was a larger change in $\operatorname{sign}\left(U=9 \cdot 5, n_{1}=6, n_{2}=\right.$ $9, P<0.02$ ) between the months before (January, February), and after (May, August), oestrus in the Busen herd. This was indicative of a high ovulation rate, and there was a higher frequency $\left(\chi^{2}\right.$ $=5.52$, d.f. $=1, P<0.025$ ) of secondary CL in the Busen than in the Barff herd (Table 1).

A luteal structure of $2 \mathrm{~mm}$ diameter was found in one calf out of 5 collected after oestrus; the cells were unvacuolated and had a mean diameter of $21.4 \pm 0.8 \mu \mathrm{m}$ compared with $29.1 \pm 0.7 \mu \mathrm{m}$ for that of a $\mathrm{CL}$ of pregnancy. Furthermore, $45 \%$ of females aged 1 year at the previous calving season $(\mathrm{N}=11)$ had from 1 to 3 luteal scars, even though there were no signs of pregnancy in this age class (Leader-Williams, 1980). Thus, many $(55 \%)$ females $>2$ years of age $(\mathrm{N}=38)$ had a higher scar count than was expected for their age class. The regression of luteal scars $(y)$ on age $(x)$ was highly significant $(r=0.86, P<0.001)$, and of the form $y=-0.05+0.97 x$; the slope did not $\operatorname{differ}(F=1 \cdot 88$, d.f. $=1,200, P>0 \cdot 10)$ from that of the Barff herd, but the difference between intercepts was highly significant $(F=32.90$, d.f. $=1,201, P<0.001)$. Data from 2 non-breeding females are shown in Table 2.

\section{Discussion}

Several factors could underlie differences in female reproductive rates between different populations of the same species. The present study allows an intraspecific comparison of ovarian characteristics of Canadian barren-ground caribou (Dauphiné, 1978) and Norwegian reindeer introduced into South Georgia. Although reindeer calves $<12$ months of age did not become pregnant on South Georgia (Leader-Williams, 1980), this has been recorded under excellent range conditions elsewhere (Palmer, 1934; Skuncke, 1969; Reimers, 1972); caribou, by contrast, do not first breed until 2 or 3 years of age (Dauphiné, 1976). In this study, reindeer calves had about 3 times as many follicles $>2 \mathrm{~mm}$ in diameter as nulliparous caribou $<36$ months of age (Text-fig. 1; Dauphiné, 1978). However, reindeer calves did not show any increase in ovarian weights or follicle numbers, and only 1 luteal structure, probably a CL of ovulation, was found in 1 calf from the Busen herd. It is therefore concluded that female reindeer on South Georgia did not attain physiological puberty as calves. Females thus differ from males, in which the onset of puberty is apparently not flexible and occurs in reindeer and caribou calves (Leader-Williams, 1979a) at an age well before they are physically able to breed.

Reindeer on South Georgia first conceived as yearlings and attained $90 \%$ pregnancy rates, in contrast to the following for caribou: $2 \%$ as yearlings; $48 \%$ as 2 -year-olds; $82 \%$ as 3 -year-olds; $90 \%$ for $\geqslant 4$-year-olds (Dauphiné, 1976). A number of caribou had not undergone a cycle of ovarian activity even by 36 months of age (Dauphiné, 1978) and this study has shown that ovaries of breeding reindeer were very active and developed about twice the number of follicles $>2 \mathrm{~mm}$ in diameter (Text-fig. 2) and of secondary CL (Table 1) as did those of caribou. High frequencies of occurrence of secondary $\mathrm{CL}$ indicate that reindeer have a higher ovulation rate than caribou, even though this parameter was not estimated in this study.

Dauphine (1978) noted that secondary CL in caribou formed around the same time as CL of pregnancy and persisted throughout gestation. Our data support this suggestion as follows: (1) no CL were found in March before pregnancies were first recorded, in contrast to black-tailed deer, Odocoileus hemionus, which first ovulate during a 'silent' heat (Thomas \& Cowan, 1975); (2) secondary CL in reindeer were present in April and throughout gestation in similar proportions, without evidence of degeneration until parturition. In this respect reindeer and caribou are most 
similar to red deer, Cervus elaphus, and elk (wapiti), C. canadensis, which do not have 'silent' heats, bear single young and yet of which $>35 \%$ of females have secondary CL, the function of which still remains unknown (Morrison, 1960; Kelly \& Challies, 1978).

The persistence of CL of ovulation and accessory or secondary CL has resulted in inaccurate determinations of the productivity of black-tailed deer and elk from regressions of luteal scars on age (Golley, 1957; Morrison, 1960). In other studies of cervids, however, such regressions have been of value, including that for caribou (Simkin, 1965; Thomas, 1970; Mansell, 1971; Dauphiné, 1978). Signs of regressing secondary CL had disappeared in caribou ovaries by 5 months post partum (Dauphiné, 1978), in contrast to those of reindeer. In spite of the overcount of luteal scars relative to age in a proportion of reindeer, regression accurately reflected their reproductive performance, especially in the larger Barff sample. These regressions, and that of $y=-1.45+$ $0.84 x$ for caribou with its low intercept (Dauphiné, 1978), also reflected differences in the ages at first breeding.

Further differences are evident between reindeer and caribou ovaries, and indeed between reindeer ovaries from Norway and in different herds on South Georgia. CL of pregnancy occurred more frequently in one of a pair of caribou ovaries (Dauphiné, 1978), but were more equally distributed in reindeer ovaries (Text-fig. 3). There was no transmigration of the fetus in South Georgia reindeer, although Roine (1970) commonly observed this in Norway. Differences between the herds on South Georgia were seen in the large number of follicles in the Royal Bay herd, and the high frequency of secondary CL and appearance of luteal structures in calves (with the resultant large overcount of scars) in the Busen herd. These differences, for which there appears no firm explanation, illustrate the inadvisability of documenting species characteristics from single studies.

In conclusion, the study has demonstrated large numerical differences in ovarian structures of reindeer and caribou, which largely reflect differences in their reproductive performances. However, the study raises the question of whether these differences arise from genetic causes or are environmentally induced. Red deer on a high plane of nutrition, and therefore with heavy body weights and large fat reserves, have increased fertility (Hamilton \& Blaxter, 1980). The paradox, as yet unanswered for reindeer and caribou, lies in the fact that the barren-ground caribou studied by Dauphiné (1978) had considerably heavier body weights and more stable fat reserves than did the South Georgia reindeer (Leader-Williams \& Ricketts, 1982a, b), although the latter had more active ovaries and better reproductive performances.

We thank Mr R. M. Pratt for assistance with fieldwork; Dr H. M. Dott, Mr T. C. Dauphiné and Mr I. L. Boyd for helpful comments; Mr A. Sylvester for preparation of text-figures; and other members of the British Antarctic Survey for help in preparing the manuscript for submission.

\section{References}

Bergerud, A.T. (1975) The reproductive season of Newfoundland caribou. Can. J. Zool. 53, 1213-1221.

Borozdin, E.K. (1969) [Histological structure of the ovary and development of oocytes in reindeer.] $\mathrm{Tr}$. Nauchno-Issled. Inst. sel'sk. Khoz. Krainego Sev. 17, 85-93. [In Russian.]

Dauphiné, T.C. (1976) Biology of the Kaminuriak population of barren-ground caribou. 4. Growth, reproduction and energy reserves. Can. Wildl. Sert. Rep. Ser. 38, 1-69.

Dauphiné, T.C. (1978) Morphology of the barren-ground caribou ovary. Can. J. Zool. 56, 1684-1696.

Dauphiné, T.C. \& McClure, R.L. (1974) Synchronous mating in Canadian barren-ground caribou. J. Wildl. Mgmt 24, 250-258.
Dott, H.M. \& Utsi, M.N.P. (1973) Artificial insemination of reindeer (Rangifer tarandus). J. Zool., Lond. 170, 505-508.

Golley, F.B. (1957) An appraisal of ovarian analysis in determining reproductive performance of blacktailed deer. J. Wildl. Mgmt 21, 62-65.

Hamilton, W.J. \& Blaxter, K.L. (1980) Reproduction in farmed red deer. I. Hind and stag fertility. J. agric. Sci., Camb. 95, 261-273.

Harrison, R.J. (1962) The structure of the ovary in mammals. In The Ovary, lst edn, Vol. 1, pp. 143-187. Ed. S. Zuckerman. Academic Press, New York.

Holthe, V. (1975) Calving season in different populations of wild reindeer in South Norway. Biol. Papers Univ. Alaska, Spec. Rep. 1, 194-198. 
Kelly, R.W. \& Challies, C.N. (1978) Incidence of ovulation before the onset of the rut and during pregnancy in the red deer hind. N. Z. Jl. Zool. 5, 817819.

Leader-Williams, N. (1979a) Age-related changes in the testicular and antler cycles of reindeer, Rangifer tarandus. J. Reprod. Fert. 57, 117-126.

Leader-Williams, N. (1979b) Age determination of reindeer introduced into South Georgia. J. Zool., Lond. 188, 501-515.

Leader-Williams, N. (1980) Population dynamics and mortality of reindeer introduced into South Georgia. J. Wildl. Mgmt 44, 640-657.

Leader-Williams, N. \& Ricketts, C. (1982a) Seasonal and sexual patterns of growth and condition of reindeer introduced into South Georgia. Oikos 38, 27-39.

Leader-Williams, N. \& Ricketts, C. (1982b) Growth and condition of three introduced reindeer herds on South Georgia: the effects of diet and density. Holarctic Ecology 5, 381-388.

Mansell, W.D. (1971) Accessory corpora lutea in ovaries of white-tailed deer. J. Wildl. Mgmt 35, 369-374.

Morrison, J.A. (1960) Ovarian characteristics in elk of known breeding history. J. Wildl. Mgmt 24, 297-307.

Olstad, O. (1930) Rats and reindeer in the Antarctic. Det. Norske Videnskaps-Akademi i Oslo. Sci. Results Norwegian Antarctic Expeditions 4, 1-19.
Palmer, L.J. (1934) Raising reindeer in Alaska. U.S. Dept. Agric., Misc. Pub. 207, 1-41.

Preobrazhenskii, B.W. (1961) Management and breeding of reindeer. In Reindeer Husbandry (translated and published by Israel Program for Scientific Translations, Jerusalem 1969), pp. 78-128. Ed. P. S. Zhigunov.

Reimers, E. (1972) Growth in domestic and wild reindeer in Norway. J. Wildl. Mgmt 36, 612-619.

Roine, K. (1970) Biometric observations of the genital organs of the reindeer cow. Proc. Nordic Vet. Congr. 11, 262.

Simkin, D.W. (1965) Reproduction and productivity of moose in Northwestern Ontario. J. Wildl. Mgmt 29, $740-750$.

Skuncke, F. (1969) Reindeer ecology and management in Sweden. Biol. Papers Univ. Alaska 8, 1-181.

Thomas, D.C. (1970) The ovary, reproduction and productivity of female Columbian black-tailed deer. Ph.D. thesis, University of British Columbia, Vancouver.

Thomas, D.C. \& Cowan, I.McT. (1975) The pattern of reproduction in female Columbian black-tailed deer, Odocoileus hemionus virginianus. J. Reprod. Fert. 44, 261-272.

Received 2 March 1982 